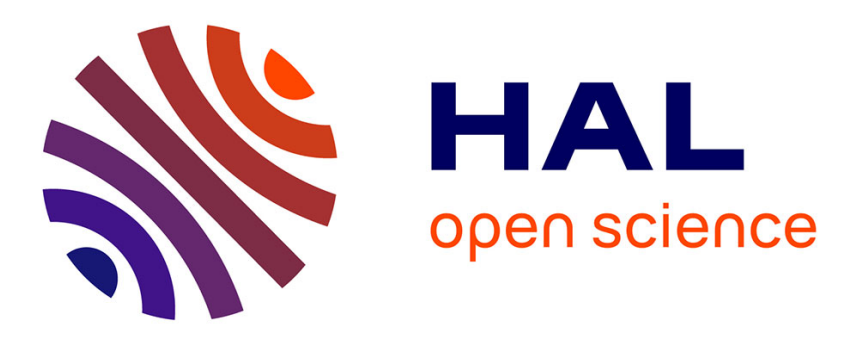

\title{
Selection of nerolidol among a series of terpenic and phenolic compounds for its potent activity against Lactobacillus fermentum ATCC 9338
}

Elissa Ephrem, Amal Najjar, Catherine Charcosset, Hélène Greige-Gerges

\section{- To cite this version:}

Elissa Ephrem, Amal Najjar, Catherine Charcosset, Hélène Greige-Gerges. Selection of nerolidol among a series of terpenic and phenolic compounds for its potent activity against Lactobacillus fermentum ATCC 9338. Process Biochemistry, 2019, 80, pp.146-156. 10.1016/j.procbio.2019.02.015 . hal-03033836

\section{HAL Id: hal-03033836 \\ https://hal.science/hal-03033836}

Submitted on 8 Dec 2020

HAL is a multi-disciplinary open access archive for the deposit and dissemination of scientific research documents, whether they are published or not. The documents may come from teaching and research institutions in France or abroad, or from public or private research centers.
L'archive ouverte pluridisciplinaire HAL, est destinée au dépôt et à la diffusion de documents scientifiques de niveau recherche, publiés ou non, émanant des établissements d'enseignement et de recherche français ou étrangers, des laboratoires publics ou privés. 
1 Selection of nerolidol among a series of terpenic and phenolic compounds for

2 its potent activity against Lactobacillus fermentum ATCC 9338

3 Elissa Ephrem ${ }^{a, b}$, Amal Najjar ${ }^{a}$, Catherine Charcosset ${ }^{\text {b }}$, Hélène Greige-Gerges ${ }^{a, *}$

$4{ }^{a}$ Bioactive Molecules Research Laboratory, Faculty of Sciences, Lebanese University, B.P.

590656 Jdaidet El-Matn, Lebanon.

6 b Laboratoire d'Automatique et de Génie des Procédés, Université Claude Bernard Lyon I,

7 France, 43 Boulevard du 11 Novembre 1918, Bâtiment CPE 69 622, Villeurbanne Cedex,

8 France.

9 *Corresponding author: Faculty of Sciences, Bioactive Molecules Research Laboratory,

10 Lebanese University, B.P. 90656 Jdaidet El-Matn, Lebanon.

11 Tel.: +9613 341011; Fax: +961 1689647

12 E-mail addresses: greigegeorges@ yahoo.com, hgreige@ul.edu.lb (Hélène Greige-Gerges). 


\section{Abstract}

23 Essential oil components are widely used for their antibacterial activity against spoilage

24 microorganisms in food. Lactobacillus fermentum is a Gram-positive lactic acid bacteria 25 responsible for the deterioration of various food products, including beverages and dairy 26 products. In this study, 17 terpenic and 11 phenolic compounds were screened against the food 27 spoilage microorganism Lactobacillus fermentum ATCC 9338. The antibacterial activity of the 28 tested compounds was dependent on hydrophobicity and particular chemical features. Nerolidol 29 solubilized in dimethylsulfoxide exhibited the highest antibacterial activity and showed low 30 minimal inhibitory (MIC: $25 \mu \mathrm{M}$ ) and minimal bactericidal (MBC: $50 \mu \mathrm{M}$ ) concentrations.

31 Moreover, no viable cells were detected within $16 \mathrm{~h}$ of incubation at $50 \mu \mathrm{M}$. The important 32 antibacterial activity of nerolidol against L. fermentum is probably related to the high 33 hydrophobicity, the aliphatic chain length, and the presence of the hydroxyl group. 34 Hydroxypropyl- $\beta$-cyclodextrin/nerolidol inclusion complex showed MIC and MBC values of 35100 and $200 \mu \mathrm{M}$, respectively. The total bacterial kill was observed after $12 \mathrm{~h}$ of incubation. The 36 results obtained with the inclusion complex are probably due to the time required to allow 37 nerolidol to be released from the inclusion complex.

38 Keywords: Cyclodextrins; Lactobacillus fermentum; nerolidol; phenolic compounds; terpenes.

39 List of abbreviations: CFU: colony forming unit; DMSO: dimethylsulfoxide; HP- $\beta$-CD: 40 hydroxypropyl- $\beta$-cyclodextrin; HPLC: high performance liquid chromatography; LAB: lactic 41 acid bacteria; MBC: minimal bactericidal concentration; MIC: minimal inhibitory concentration; 42 Ner: nerolidol. 


\section{Introduction}

45 Lactobacillus fermentum is an ubiquitous Gram-positive, rod-shaped, anaerobic, thermo46 acidophilic lactic acid bacteria (LAB), which can originate from plants, animals, meat, dairies,

47 fruits, and cereals. L. fermentum is an obligate heterofermentative bacteria which ferments

48 various types of sugars (lactose, fructose, maltose, sucrose) under anaerobic conditions. In 49 addition to lactic acid, L. fermentum produces acetic acid, ethanol, carbon dioxide, and minor by50 products, such as diacetyl, hydrogen peroxide, and different alcohols (e.g. 3-methylbutanol), 51 esters (e.g. ethyl acetate), and carbonyls (e.g. nonanal) compounds. L. fermentum is not harmful 52 to humans and its presence is necessary for the fermentation of different food products, including 53 sourdough, cocoa, and certain beverages. Certain L. fermentum strains are probiotic agents and 54 express outstanding health-promoting characteristics when consumed [1]. Nonstarter lactic acid 55 bacteria, including L. fermentum, cause defects in certain food products, such as slits or cracks in 56 hard cheeses, lack of flavors, or bloated packaging in dairy products [2-4]. L. fermentum also 57 spoils various types of beverages and can grow in fruit juice, leading to the production of 58 undesirable compounds [5-9]. It is one of the LABs responsible for the desired malolactic 59 fermentation in wine, resulting in the conversion of malic acid into lactic acid, acetate, succinate, 60 and carbon dioxide [10]. However, the presence of LABs could lead to wine spoilage as the 61 control of bacterial growth and malolactic fermentation is difficult to achieve, thus altering the 62 wine organoleptic properties [10-12]. The growth of heterofermentative LABs (such as $L$. 63 fermentum) in wine causes an increased acidity, cloudiness, and mousy odor [13]. On the other

64 hand, L. fermentum can grow in beer, as it is resistant to hop-compounds [14], leading to beer 65 spoilage $[14,15]$ and aroma alteration [14]. 
Different strategies have been adopted to overcome the microbial spoilage of food, including the

67 addition of chemical additives and physical treatments. Physical treatments include various preservation techniques, such as thermal, ultraviolet light, ultrasound, pulsed electric field, and

69 high hydrostatic pressure technologies [16]. However, the application of these treatments is

70 limited due to changes in the organoleptic properties of the food product [17-19] and sometimes

71 due to high cost [20]. On the other hand, chemical preservatives used against food microbial

72 spoilage, including benzoates, sorbates, propionates, nitrates, and nitrites, can cause allergic

73 responses and could be converted to potential carcinogens [21]. The high demand of fresh and

74 "safe" food, free of synthetic additives and contaminants, have increased the interest of using

75 natural products for food preservation. Natural antimicrobials may derive from plants, animals,

76 and microorganisms. Plant essential oils are largely exploited due to their wide spectrum of

77 antimicrobial activity against spoilage bacteria and food-borne pathogens [22]. Plant

78 antimicrobials include different chemical classes, among which are saponins, tannins, flavonoids,

79 terpenes, simple phenols, and phenolic acids [23,24].

80 The majority of natural antimicrobials are hydrophobic and poorly stable, which limit their use in

81 aqueous media. Solvents, such as dimethylsulfoxide (DMSO) [25], dimethylformamide [26], and

82 ethanol [27, 28], are used to dissolve hydrophobic compounds in aqueous solutions. However,

83 the use of organic solvents in food products is not desirable. Various encapsulation systems

84 (nanoemulsions, liposomes, nanoparticles, solid lipid nanoparticles, cyclodextrins, etc.) were

85 introduced to the food industry as a novel strategy to overcome the poor water solubility of food

86 antimicrobials and to enhance their stability in food matrices [29,30]. Cyclodextrins are natural

87 oligosaccharides widely used in food products for their safety and their ability to deliver 
89 derivatives of cyclodextrin have been synthetized to enhance the aqueous solubility of native 90 cyclodextrins [32].

91 The objective of this study is to select a natural potent antibacterial agent against L. fermentum.

92 The selected antibacterial is then complexed with hydroxypropyl- $\beta$-cyclodextrin $(\mathrm{HP}-\beta-\mathrm{CD})$ and

93 the obtained inclusion complex is tested against the chosen bacterium in culture medium.

94 Therefore, a wide range of terpenic and phenolic phytochemicals was screened against the

95 bacterium, under its optimal growth conditions. The tested compounds belong to different

96 subclasses and possess variable structures. Seventeen terpenes were tested, among which eight

97 monoterpene hydrocarbons (camphene, $p$-cymene, limonene, $\alpha$-phellandrene, $\alpha$-pinene, $\beta$ -

98 pinene, $\alpha$-terpinene, $\gamma$-terpinene), a sesquiterpene hydrocarbon ( $\beta$-caryophyllene), four

99 monoterpene alcohols (borneol, geraniol, linalool, menthol), a sesquiterpene alcohol (nerolidol),

100 two monoterpene esters (bornyl acetate, linalyl acetate), and a monoterpene ketone (camphor)

101 (Fig. 1). In addition, eleven phenols were tested, among which four phenylpropenes (trans102 anethole, eugenol, isoeugenol, estragole), a phenylpropene ester (eugenyl acetate), two 103 hydroxycinnamic acids ( $p$-coumaric acid, trans-ferulic acid), a phenol ether (anisole), a 104 methylphenol (o-cresol), a flavonoid (quercetin), and a stilbenoid (resveratrol) (Fig. 2).

105 Nerolidol (Ner) showed the most potent antibacterial activity against L. fermentum among the 28 106 tested compounds. The potency of nerolidol solubilized in DMSO and hydroxypropyl- $\beta$ 107 cyclodextrin/nerolidol (HP- $\beta-\mathrm{CD} / \mathrm{Ner}$ ) complex was assessed against L. fermentum by 108 determining the minimal inhibitory concentration (MIC) and the minimal bactericidal 109 concentration (MBC) values under the optimal conditions for L. fermentum growth. The time 110 required for both forms of nerolidol to cause a total bacterial kill was determined by time-kill 111 analysis. 


\section{2. Materials and methods}

113 2.1. Materials

$114 \beta$-Caryophyllene, geraniol, isoeugenol (98\% mixture cis and trans), nerolidol (98\%, mixture of 115 cis $(40 \%)$ and trans (60\%) isomers), (-)- $\beta$-pinene, ethanol, and DMSO were purchased from 116 Sigma-Aldrich (Missouri, United States). trans-Anethole (99\%) and linalyl acetate were 117 purchased from Sigma-Aldrich (Madrid, Spain). Anisole, camphene, $o$-cresol, eugenol, eugenyl 118 acetate, (-)-menthol, and $\alpha$-phellandrene were purchased from Sigma-Aldrich (Schnelldorf, 119 Germany). (-)-Borneol, (-)-bornyl acetate, $p$-cymene, (R)-(t)-limonene, linalool, (+)- $\alpha$-pinene, $\alpha$ 120 terpinene, and $\gamma$-terpinene were purchased from Sigma-Aldrich (Buchs, Switzerland). ( \pm )121 Camphor and trans-ferulic acid were purchased from Sigma-Aldrich (Hong Kong, China). 122 Quercetin was purchased from Sigma-Aldrich (Haryana, India). $p$-Coumaric acid was purchased 123 from Sigma-Aldrich (Irvine, United kingdom). Hydroxypropyl- $\beta$-cyclodextrin was purchased 124 from Wacker-Chemie (Lyon, France). De Man, Rogosa, and Sharpe (MRS) broth and MRS agar 125 were purchased from Laboratorios Conda (Madrid, Spain).

126 2.2. Bacterial strain and culture

127 L. fermentum ATCC 9338 was purchased from American Type Culture Collection (Manassas, 128 Virginia, USA). L. fermentum cultures were routinely maintained at $4{ }^{\circ} \mathrm{C}$ on MRS agar. Before 129 each antimicrobial assay, fresh cultures were prepared in sterile MRS broth and incubated at 37 $130{ }^{\circ} \mathrm{C}$ for $22 \mathrm{~h}$ under anaerobic conditions. A bacterial suspension was prepared by diluting the 131 bacterial culture in MRS broth to a final concentration of $25 \times 10^{5}$ colony forming unit (CFU)/ml. 
132 2.3. Screening of natural terpenic and phenolic compounds for antibacterial activity

133 2.3.1. Screening rounds

134 Twenty-eight natural terpenic and phenolic compounds were screened for their antibacterial 135 activity against L. fermentum at 3500, 500, 250, and $100 \mu \mathrm{M}$. The tested molecules were 136 dissolved in DMSO, except $\beta$-caryophyllene and camphene which were dissolved in ethanol, and 137 the obtained solutions were homogenized by hand agitation prior to each test. Antibacterial agent 138 solutions $(25 \mu \mathrm{l})$ were mixed with MRS broth $(4.8 \mathrm{ml})$ in glass culture tubes $(20 \times 100 \mathrm{~mm})$. The 139 tubes were then inoculated with $200 \mu$ of a diluted L. fermentum suspension $\left(25 \times 10^{5} \mathrm{CFU} / \mathrm{ml}\right)$ 140 to yield a bacterial concentration of $10^{5} \mathrm{CFU} / \mathrm{ml}$ at baseline. Bacterial cultures (5 ml) exempt of 141 any agent, or containing $25 \mu \mathrm{l}$ of DMSO or ethanol, served as controls. All cultures were 142 incubated at $37{ }^{\circ} \mathrm{C}$ for $22 \mathrm{~h}$ under anaerobic conditions. Screening rounds were conducted with 143 bioactive compounds at 3500, 500, and $250 \mu \mathrm{M}$, successively. After each screening round, 144 molecules demonstrating an anti-proliferative activity against L. fermentum at a given 145 concentration were identified. Whereas, compounds demonstrating a bactericidal effect against 146 L. fermentum were selected for another screening round at a lower concentration. The 147 compounds exhibiting a total bactericidal activity or a total anti-proliferative activity against $L$. 148 fermentum at $250 \mu \mathrm{M}$ were screened at $100 \mu \mathrm{M}$. Each test was performed in triplicate and under 149 sterile conditions.

150 2.3.2. Determination of the anti-proliferative activity of molecules

151 The anti-proliferative activity of the molecules against L. fermentum was assessed by UV-visible 152 spectroscopy at $660 \mathrm{~nm}$ using Uviline 9100-9400 spectrophotometer (GmbH, Germany). The 153 optical density of each tube was measured and compared to the control. The percentage of 154 bacterial proliferation inhibition was calculated as follows: 
156 where $\mathrm{OD}_{660 \mathrm{~m}}$ and $\mathrm{OD}_{660 \mathrm{c}}$ are the optical densities of the tubes containing the molecule and the 157 control tube, respectively. Each test was done in triplicate.

158 2.3.3. Determination of the bactericidal activity of the natural molecules

159 Cultures showing a total inhibition of bacterial proliferation were analyzed in duplicate by 160 spreading an aliquot of $100 \mu \mathrm{l}$ on MRS agar. The bacterial concentration in the control was 161 determined by enumeration. The bactericidal capacity was then evaluated according to the 162 decrease in the initial bacterial concentration and calculated as follows:

$$
\text { Bacterial kill }(\%)=100 \times\left[1-\frac{[b a c] m}{[b a c] c}\right] \text {, }
$$

164 where $[\mathrm{bac}]_{\mathrm{m}}$ and $[\mathrm{bac}]_{\mathrm{c}}$ are the bacterial concentrations in the tube containing the molecule and 165 the control tube, respectively.

\subsection{Preparation of HP- $\beta-\mathrm{CD} / \mathrm{Ner}$ inclusion complex}

167 HP- $\beta$-CD/Ner inclusion complex was prepared by freeze-drying, as previously described by Azzi

168 et al. [33]. Briefly, an aqueous solution of HP- $\beta-C D(25 \mathrm{mM})$ containing an excess of nerolidol 169 was kept under magnetic stirring at $300 \mathrm{rpm}$ for $24 \mathrm{~h}$ at room temperature. The suspension was 170 then filtered $(0.45 \mu \mathrm{m}$, cellulose acetate membrane) to remove the excess of nerolidol. The 171 filtrate was frozen at $-80{ }^{\circ} \mathrm{C}$, and lyophilized. HP- $\beta$-CD/Ner complex in powder form was stored 172 at $4{ }^{\circ} \mathrm{C}$ until usage. The amount of nerolidol encapsulated in the cyclodextrin cavity was 173 determined by HPLC as described previously by Azzi et al. [33], and the result was expressed as 174 mass of nerolidol $(\mu \mathrm{g})$ per mg of powder $\left(\mu \mathrm{g}_{\mathrm{Ner}} / \mathrm{mg}_{\text {powder }}\right)$. 
175 2.5. Study of the antibacterial activity of nerolidol and HP- $\beta$-CD/Ner complex

176 2.5.1. Determination of MIC and MBC values

177 Bacterial cultures were prepared as previously described in section 2.3.1, in presence of nerolidol 178 dissolved in DMSO, and added at a final concentration ranging from 0.1 to $3500 \mu \mathrm{M}$. The MIC 179 was determined as the minimal concentration at which no bacterial growth was observed in MRS 180 broth, whereas the MBC was determined as the minimal concentration at which no bacterial 181 growth was observed on agar. Each experiment was performed in triplicate and under sterile 182 conditions. On the other hand, HP- $\beta-\mathrm{CD}$ was investigated for its capacity to replace DMSO for 183 nerolidol solubilization in aqueous solution. The inclusion complex was tested at a final 184 concentrations of nerolidol ranging between 50 and $4000 \mu \mathrm{M}$. Bacterial cultures (5 ml) exempt 185 of any agent, or containing DMSO $(25 \mu \mathrm{l})$ or blank HP- $\beta-\mathrm{CD}$ added in similar amounts to that of 186 the inclusion complex, served as controls.

187 2.5.2. Time-kill analysis

188 Time-kill assay was performed in triplicate on nerolidol and HP- $\beta-\mathrm{CD} / \mathrm{Ner}$ complex. Cultures 189 were prepared as described in section 2.3.1. Nerolidol solubilized in DMSO and the complex 190 were added to cultures at their respective MBC values. Starting from an initial bacterial 191 concentration of $10^{5} \mathrm{CFU} / \mathrm{ml}(5 \log \mathrm{CFU} / \mathrm{ml})$, bacterial growth was followed during $22 \mathrm{~h}$ in 192 cultures maintained at $37^{\circ} \mathrm{C}$ under anaerobic conditions. The viable plate count was determined 193 at different time intervals using the spread plate method [34]. Therefore, $100 \mu$ of samples with 194 appropriate dilutions was spread on MRS agar. The plates were incubated under L. fermentum 195 optimal growth conditions for $22 \mathrm{~h}$. The colonies were then counted and the bacterial 196 concentration was determined. 


\subsection{Statistical Analysis}

Statistical analysis was performed using the Student T test. $P$ values equal or less than 0.05 were considered statistically significant.

\section{Results}

3.1. Antibacterial activity of terpenic and phenolic compounds

Terpenic compounds exhibited a significantly higher antibacterial activity against L. fermentum compared to phenolic compounds, with $\alpha$-terpinene being the only exception. In fact at $3500 \mu \mathrm{M}$, 16 among the 17 tested terpenes were bactericidal, whereas $\alpha$-terpinene strongly inhibited the proliferation of L. fermentum (89.1\%) (Table 1). Eugenol and its ester derivative eugenyl acetate were the only phenolic compounds exhibiting a strong bactericidal activity against $L$. fermentum at $3500 \mu \mathrm{M}$. Indeed, eugenol and eugenyl acetate exhibited a bactericidal activity of $100 \%$ and $95 \%$, respectively, within $22 \mathrm{~h}$ of incubation at $37{ }^{\circ} \mathrm{C}$ under anaerobic conditions (Table 2). Among the phenolic compounds, trans-anethole, estragole, and isoeugenol showed a significant anti-proliferative activity against $L$. fermentum at the highest concentration $(3500 \mu \mathrm{M})$, where bacterial growth inhibition was higher than $88 \%$ (Table 2). At this concentration, $p$-coumaric acid, trans-ferulic acid, and anisole showed a weak bacterial growth inhibition of 21.9, 17.3, and $16.1 \%$, respectively (Table 2). Whereas, quercetin, $o$-cresol, and resveratrol possessed no antibacterial activity against $L$. fermentum (Table 2). In fact, quercetin and resveratrol were insoluble in MRS at this concentration, which was marked by their strong precipitation.

The stronger antibacterial property of terpenes compared to phenolic compounds was highlighted by the strong bactericidal and anti-proliferative effect of different studied terpenes at $500 \mu \mathrm{M}$. Indeed, at this concentration, the two phenolic compounds, eugenol and eugenyl acetate, showed no antibacterial activity against L. fermentum (Table 2). On the other hand, $\beta$-pinene, bornyl 
220 acetate, linalyl acetate, and nerolidol exhibited a total bactericidal activity at $500 \mu \mathrm{M}$ (Table 1).

221 Camphene, $p$-cymene, limonene, $\alpha$-phellandrene, $\alpha$-pinene, and $\gamma$-tepinene showed a total

222 inhibition of L. fermentum proliferation but were not bactericidal (Table 1). Furthermore, $\beta$ -

223 caryophyllene, geraniol, and menthol showed a bacterial inhibition percentage higher than $75 \%$,

224 compared to control, whereas borneol demonstrated a weak anti-proliferative activity $(28.5 \%)$

225 (Table 1). However, linalool and camphor, which exhibited a bactericidal activity against $L$.

226 fermentum at $3500 \mu \mathrm{M}$, showed no antibacterial activity at $500 \mu \mathrm{M}$ (Table 1).

227 When $\beta$-pinene, bornyl acetate, linalyl acetate, and nerolidol were tested at $250 \mu \mathrm{M}$, nerolidol

228 was the only compound exhibiting a bactericidal activity (100\%) (Table 1). Whereas, $\beta$-pinene, 229 bornyl acetate, and linalyl acetate showed a strong anti-proliferative activity against $L$. 230 fermentum at $250 \mu \mathrm{M}$, as no bacterial growth was observed in MRS broth within $22 \mathrm{~h}$ of 231 incubation (Table 1). Nerolidol maintained a strong bactericidal activity (100\%) against $L$. 232 fermentum at $100 \mu \mathrm{M}$, whereas, $\beta$-pinene strongly inhibited bacterial proliferation ( 91\%), and 233 bornyl acetate and linalyl acetate showed no antibacterial activity (Table 1). Thus, among the 28 234 tested compounds, nerolidol was retained for further studies as it was the most effective studied 235 compound against L. fermentum.

236 3.2. Antibacterial activity of nerolidol

237 Nerolidol was the only molecule that exhibits a bactericidal activity against L. fermentum at a 238 low concentration $(100 \mu \mathrm{M})$ (Tables 1 and 2). Therefore, the study was taken further to 239 determine the MIC and MBC values of nerolidol. Nerolidol exhibited a strong antibacterial 240 activity against $L$. fermentum with low MIC $(25 \mu \mathrm{M} ; 5.56 \mathrm{mg} / \mathrm{l})$ and MBC $(50 \mu \mathrm{M} ; 11.12 \mathrm{mg} / \mathrm{l})$ 241 values. Moreover, L. fermentum survival was approximately $1 \%$ at a nerolidol concentration of 
$24235 \mu \mathrm{M}$. However, the adopted MBC was $50 \mu \mathrm{M}$, as no bacterial growth was observed at this 243 concentration.

244 The antibacterial activity profile (bactericidal or bacteriostatic) of nerolidol was evaluated using 245 the MBC to MIC ratio. The in vitro antimicrobial activity of nerolidol can be described as 246 bactericidal as the $\mathrm{MBC}$ to $\mathrm{MIC}$ ratio $(\mathrm{MBC} / \mathrm{MIC}=2)$ is lower than 4 [35].

247 3.3. Antibacterial activity of HP- $\beta-\mathrm{CD} / \mathrm{Ner}$ complex

248 The amount of nerolidol in the freeze-dried inclusion complex, determined by HPLC, was 40 $249 \mu \mathrm{g}_{\mathrm{Ner}} / \mathrm{mg}_{\text {powder. }}$. The antibacterial activity of HP- $\beta-\mathrm{CD} / \mathrm{Ner}$ complex was investigated for the first 250 time against L. fermentum in culture medium under the optimal conditions for bacterial growth. 251 HP- $\beta$-CD without nerolidol had no effect on the bacterial growth (data not shown). The MIC and $252 \mathrm{MBC}$ values of HP- $\beta-\mathrm{CD} / \mathrm{Ner}$ against L. fermentum were 100 and $200 \mu \mathrm{M}$, respectively. At 50 $253 \mu \mathrm{M}$, a $4 \log$ increment was observed in the bacterial concentration within $22 \mathrm{~h}$ of incubation 254 (data not shown).

255 3.4. Nerolidol and HP- $\beta$-CD/Ner complex time-kill analysis

256 A time-kill analysis was conducted to determine the time required to achieve a total bacterial kill 257 in presence of nerolidol solubilized in DMSO at $50 \mu \mathrm{M}$ and HP- $\beta$-CD/Nero complex at $200 \mu \mathrm{M}$ 258 (MBC). Free nerolidol exhibited a bactericidal activity against L. fermentum within the first few 259 hours of incubation (Fig. 3). Indeed, a $1.44 \log$ reduction of L. fermentum concentration was 260 observed within $4 \mathrm{~h}$ of incubation. The bacterial concentration continued to decrease over time, 261 as a $2.82 \log$ reduction was obtained after $10 \mathrm{~h}$. At $16 \mathrm{~h}$ of incubation, no viable cells were 262 observed. 
263 In presence of HP- $\beta-\mathrm{CD} /$ Ner complex $(200 \mu \mathrm{M})$, the bacterial concentration decreased by 1.22

$264 \log$ and $2.44 \log$ after 4 and $10 \mathrm{~h}$, respectively, and a total bacterial death was obtained within 12

265 h (Fig. 3).

\section{4. Discussion}

267 4.1. Antibacterial efficiency of nerolidol

268 Plants produce a wide range of antimicrobial agents highly desired by consumers due to their

269 natural origin. However, many of these antimicrobials are only effective at high concentrations

270 (for example at millimolar range), thus exhibiting a weak activity compared to common

271 antibiotics [36]. In this study, nerolidol exhibited the highest antibacterial activity among the 28

272 tested terpenic and phenolic compounds. The outstanding antibacterial potency of nerolildol

273 against $L$. fermentum was marked by the low MIC $(25 \mu \mathrm{M} ; 5.56 \mathrm{mg} / \mathrm{l})$ and MBC $(50 \mu \mathrm{M} ; 11.12$

$274 \mathrm{mg} / \mathrm{l}$ ) values, as well as the rapid bactericidal activity (Fig. 3). This compound acts by disrupting

275 and by damaging the bacterial cell membrane, and by interfering with genes responsible for the

276 microbe pathogenicity [37]. Besides, Brehm-Stecher and Johnson [27] demonstrated the

277 permeabilizing effect of nerolidol on L. fermentum membrane. The permeabilization of the

278 bacterial membrane leads to the leakage of the cytoplasmic molecules, thus causing cell lysis

279 [38]. Also, the disruption of the bacterial membrane would allow the permeation of exogenous

280 molecules into the bacterial cytoplasm [27]. Moreover, Brehm-Stecher and Johnson [27]

281 suggested that the permeabilizing activity of nerolidol may be due to its structural resemblance to

282 the lipids of the bacterial membrane. This was previously highlighted by Cornwell and Barry

283 [39] which attributed the enhancement of skin penetration by nerolidol to its long hydrocarbon

284 tail which promotes the interaction of the molecule with the interior of the cell bilayer. 
285 Nerolidol is a sesquiterpene alcohol widely used in the food industry as a flavoring agent. It 286 demonstrated a potent antimicrobial activity against some fungi, in addition to different Gram287 positive and Gram-negative bacterial strains, such as Staphylococcus aureus (MIC: $3.9 \mathrm{mg} / \mathrm{l} ; 50$ $288 \mathrm{mg} / \mathrm{l}$ ) [26,40,41], Streptococcus mutans, Propionibacterium acnes (MIC: 25 mg/l) [26], 289 Salmonella enterica (MIC: $15.6 \mathrm{mg} / \mathrm{l}$ ) [41], Trichophyton mentagrophytes (MIC: $12.5 \mathrm{mg} / \mathrm{l}$ ) [26], 290 and Aspergillus niger (15.6 mg/l) [41]. On the other hand, nerolidol was able to enhance the 291 susceptibility of $S$. aureus and Escherichia coli to antibiotics, including ciprofloxacin, 292 erythromycin, gentamicin, vancomycin [42], and amoxicilline/clavulanic acid [43]. In this study, 293 nerolidol antibacterial potency against L. fermentum (MIC: $25 \mu \mathrm{M} ; 5.56 \mathrm{mg} / \mathrm{l}$ ) was weaker than 294 that of gentamicin [44] and chloramphenicol [45], and close to that of novobiocin [46] and N295 alkyldimethylbenzyl ammonium chloride [47] (Table 3). On the other hand, L. fermentum strains 296 were less sensitive to well-known antibiotics including vancomycin [45,48], teicoplanin [45], 297 streptomycin [44,45,48], erythromycin, tobramycin, clindamycin, kanamycin, polymixin B $298[44,46,48]$, metronidazole, and nitrofurantoin [49] (Table 3).

299 4.2. Antibacterial assay of HP- $\beta-C D / N e r$ complex

300 Cyclodextrin inclusion complexes have been widely studied for their capacity to enhance the 301 stability and solubility of antimicrobials [28,50,51].

302 Some studies reported similar antibacterial activities of free and complexed antimicrobials (e.g. 303 clarithromycin, chlorogenic acid, peptide CM4) [28,50,52], while others proved modifications of 304 the potency of the antimicrobial agent following complexation with cyclodextrins. Compared to 305 the free form, the inclusion complex of Hyptis martiusii essential oil [53] and coriander essential 306 oil [51] showed a lower antimicrobial activity, whereas that of carvacrol showed a higher 307 antimicrobial activity [54]. 
308 The incorporation of nerolidol into HP- $\beta-\mathrm{CD}$ inclusion complex increased the MIC and MBC 309 values by 4 fold. Azzi et al. [33] studied the release of nerolidol from the inclusion complex in 310 water and at room temperature by dialysis. Around $45 \%$ of nerolidol were released from HP- $\beta$ $311 \mathrm{CD} /$ Ner complex within $8 \mathrm{~h}$, followed by a slow release rate over 7 days [33]. In fact, when HP$312 \beta-\mathrm{CD} / \mathrm{Ner}$ complex is added at $50 \mu \mathrm{M}$, the actual concentration of nerolidol interacting with $L$. 313 fermentum in MRS is significantly lower than $50 \mu \mathrm{M}$ during the whole experiment, thus 314 explaining the ability of the inoculated bacteria to proliferate (data not shown). However, at 200 $315 \mu \mathrm{M}$ the concentration of nerolidol in the culture medium should be approximately $100 \mu \mathrm{M}$ after 8 316 to $10 \mathrm{~h}$ of incubation, which could explain the rapid drop in the bacterial concentration (Fig. 3). 317 The slow release and the photo-protection of nerolidol provided by the encapsulation systems 318 [33] would prevent and limit the proliferation of spoilage bacteria in food products.

319 4.3. Relationship between the antibacterial activity of terpenic and phenolic compounds and their 320 structural and physicochemical parameters

321 Various parameters may modulate the activity of antibacterial agents, including the drug

322 hydrophobicity, the presence of functional groups, the bacterial cell envelope characteristics, and 323 the incubation conditions (for instance, aeration).

324 4.3.1. The influence of hydrophobicity on the antibacterial activity of molecules

325 It has been reported that molecules with high hydrophobicity exhibit a high affinity to the 326 lipophilic structures in the target microorganisms, such as the bacterial membrane [55]. 327 Therefore, they may disrupt the membrane integrity, thus affecting membrane permeability and 328 enzymes activity [55]. However, many exceptions could be revealed from this work, which 329 suggests that the hydrophobicity is not always the key parameter governing the antibacterial 
330 activity; and some structural features could be taken into consideration when analyzing the

331 structure-antibacterial activity relationship.

332 Nerolidol, which has shown the strongest antibacterial activity against L. fermentum, has a LogP 333 value (5.33-5.36) considerably higher than that of the other tested molecules, except $\beta$ 334 caryophyllene (6.87) (Table 1 ). The latter, showed a modest antibacterial activity against $L$. 335 fermentum as it lost its bactericidal potential at $500 \mu \mathrm{M}$ (Table 1$)$. In fact, $\beta$-caryophyllene have 336 been found to exhibit a weak antibacterial activity against different Gram-positive and Gram337 negative bacteria [56].

338 On the other hand, the antibacterial potency of the compounds exhibiting an antibacterial activity 339 at a concentration lower than $500 \mu \mathrm{M}$ was influenced by hydrophobicity (Table 1). Indeed, $\beta$ 340 pinene showed a higher antibacterial activity than the less hydrophobic molecules, bornyl acetate 341 and linalyl acetate (Table 1). The acetylation of linalool and borneol increased their 342 hydrophobicity and their antibacterial activity (Table 1). Indeed, bornyl acetate and linalyl 343 acetate retained their total anti-proliferative activity at $250 \mu \mathrm{M}$, whereas borneol and linalool lost 344 partially and totally the activity at $500 \mu \mathrm{M}$, respectively (Table 1). Similarly, Knobloch et al. 345 [57] reported a higher inhibition of $\mathrm{H}^{+}$-translocation by linalyl acetate, compared to linalool. 346 Also, Dorman and Deans [58] observed a higher antibacterial activity of bornyl acetate compared 347 to borneol against a wide range of bacterial strains, among which Lactobacillus plantarum. 348 Moreover, phenolic compounds with LogP values close to or lower than 2, such as anisole (2.11) 349 and $o$-cresol (1.95-1.98), showed no or a weak antibacterial activity against L. fermentum (Table 350 2).

351 Acyclic monoterpenoids showed an increased antibacterial activity with the increment of their 352 LogP value. Indeed, linalyl acetate showed a higher antibacterial activity than geraniol, which 
353 was more potent than linalool (Table 1). This was also observed for bicyclic monoterpenes, as

354 borneol and camphor had the lowest LogP values, and showed the weakest antibacterial activities

355 (Table 1). However, despite $\beta$-pinene not being the most hydrophobic compound in the bicyclic

356 monoterpenes chemical class, it exhibited the strongest antibacterial activity (Table 1).

357 For monocyclic monoterpenes, limonene, $\alpha$-phelladrene, and $\gamma$-terpinene, having higher LogP

358 values than menthol, showed a stronger antibacterial activity (Table 1). $\alpha$-Terpinene was found

359 to be an exception as it showed the weakest antibacterial potency, despite a high $\operatorname{LogP}$ value

360 (Table 1).

4.3.2. Structure-activity analysis of terpenic compounds

362 Different studies have demonstrated the role of terpenoid functional groups in the antimicrobial 363 activity. Carvacrol showed a better antimicrobial activity compared to its derivatives, carvacrol 364 methyl ether and p-cymene, which lack the hydroxyl group [58]. On the other hand, Kotan et al. 365 [59] reported a better antibacterial activity for alcohol derivatives of oxygenated monoterpenes, 366 when compared to ketone and acetate derivatives.

367 The weak antibacterial activity of $\beta$-caryophyllene, despite its high hydrophobicity, may be due to the absence of a hydrophilic functional group in the chemical structure of the molecule. The 369 combination of a lipophilic character of the skeleton and the presence of a hydrophilic functional 370 group was found to be important for the antimicrobial activity of essential oils components [60].

371 The structural features of nerolidol are in line with the previous findings. Indeed, the 372 antibacterial activity of aliphatic terpene alcohols was demonstrated to be dependent on the 373 hydrophobic chain length starting from the carbon connected to the hydroxyl group [38,61]. In 374 fact, farnesol $\left(\mathrm{C}_{12}\right)$ exhibited a stronger antibacterial activity than nerolidol $\left(\mathrm{C}_{10}\right)$ followed by 375 geraniol $\left(\mathrm{C}_{8}\right)$, whereas linalool $\left(\mathrm{C}_{6}\right)$ showed no antibacterial activity against Staphylococcus 
aureus [61]. Similarly, Togashi et al. [38] reported a very weak antibacterial activity of geraniol and linalool against $S$. aureus. Additionally, farnesol $\left(\mathrm{C}_{12}\right)$, nerolidol $\left(\mathrm{C}_{10}\right)$, and plaunotol $\left(\mathrm{C}_{11}\right)$, showed a strong antibacterial activity against $S$. aureus, in that order [38,62]. Also, no or weak antibacterial activity against $S$. aureus was reported for alcohols with chains containing more than 12 carbon atoms like farnesylacetol $\left(\mathrm{C}_{14}\right)$ [61], geranylgeraniol, and phytol $\left(\mathrm{C}_{16}\right)$ [38]. Therefore, to exhibit a potent antibacterial effect, the authors suggested that the chain, starting from the hydroxyl group, should contain from 10 to 12 carbon atoms [38], or less than 12 carbon atoms but as close to 12 as possible [61]. Although the previous studies were conducted on $S$. aureus, our study supports the pattern of the antibacterial activity of terpene alcohols against $L$. fermentum. Indeed, nerolidol $\left(\mathrm{C}_{10}\right.$; sesquiterpene) exhibited a stronger antibacterial activity than geraniol $\left(\mathrm{C}_{8}\right.$; monoterpene), the latter being more potent than linalool $\left(\mathrm{C}_{6}\right.$; monoterpene) (Table $1)$.

\subsubsection{Structure-activity analysis of phenolic compounds}

The importance of the propenyl side chain was noted among the tested phenolic compounds, as eugenol, trans-anethole, isoeugenol, and estragole, showed a significantly higher antibacterial activity against L. fermentum compared to anisole (Table 2). The propenyl side chain is absent in anisole compared to eugenol, trans-anethole, isoeugenol, and estragole (Fig. 2), which could be the reason for the weaker antibacterial activity of anisole.

On the other hand, eugenol showed the highest antibacterial activity among the tested phenolic compounds against the Gram-positive bacterium L. fermentum. However, Gharib et al. [63] reported a higher antibacterial activity for anethole and estragole compared to eugenol, against the Gram-negative bacterium Escherichi coli. Indeed, the hydrophobicity of the compound seemed to play a role in the potency of the antibacterial activity against E. coli, as anethole and 
estragole have a higher hydrophobicity than eugenol [63] (Table 2). Whereas, the hydrophobicity of phenylpropenes did not seem to influence their antibacterial activity against the Gram-positive bacterium, $L$. fermentum. Therefore, our results strongly suggest the presence of other factors that modulate the antibacterial activity of phenylpropenes against $L$. fermentum. The higher antibacterial activity of eugenol compared to its ester, eugenyl acetate (Table 2), highlights the importance of the hydroxyl group in the phenolic structure (Fig. 2). Additionally, the absence of the hydroxyl group in trans-anethole and estragole structure (Fig. 2) could explain the lower antibacterial activity against $L$. fermentum, compared to eugenol (Table 2). Indeed, the hydroxyl group of eugenol and isoeugenol has been found to reinforce the lipid membrane-fluidizing effect, compared to anethole and estragole [63]. Also, the bacterial membrane characteristics play a crucial role in the differential bacterial susceptibility to a given antibacterial agent [6466]. In fact, eugenol has previously shown lower MIC values against the Gram-positive bacteria Staphylococcus aureus $(\mathrm{MIC}=2.5 \mathrm{mg} / \mathrm{l})$ and Bacillus subtilis $(\mathrm{MIC}=1.25 \mathrm{mg} / \mathrm{l})$, compared to $E$. coli $(\mathrm{MIC}=5 \mathrm{mg} / \mathrm{l})[67]$.

Both ferulic acid and $p$-coumaric acid exhibited a weak anti-proliferative activity against $L$. fermentum in MRS broth ( $\mathrm{pH} \sim 6.2$ ) (Table 2). The antibacterial activity of hydroxycinnamic acids depends on $\mathrm{pH}$, which controls the concentration of their undissociated form. The undissociated form can easily penetrate the cytoplasmic membrane of the bacterium [68]. The pKa values of ferulic acid and $p$-coumaric acid are between 4 and 5, thus a greater proportion of their dissociated forms is found at the $\mathrm{pH}$ of the culture medium ( 6.2). In fact, the antibacterial activity of ferulic acid and $p$-coumaric acid was found to increase in culture media at $\mathrm{pH}$ values below 6 [69]. Moreover, L. fermentum is able to metabolize ferulic acid and coumaric acid into 
421 less potent metabolites, such as phloretic acid, p-vinyl phenol, or dihydroferulic acid [69]. This

422 also may explain the weak antibacterial activity of both acids against L. fermentum.

\section{5. Conclusion}

424 In this study, 28 terpenic and phenolic compounds were screened against L. fermentum, an 425 ubiquitously present bacterium which could cause spoilage of different food products. Among 426 the tested compounds, nerolidol exhibited the strongest antibacterial activity marked by the low 427 MIC and MBC values. Moreover, a total bacterial kill was obtained within $16 \mathrm{~h}$ in presence of 428 nerolidol $(50 \mu \mathrm{M})$. The antibacterial activity of nerolidol was dependent on different factors, 429 including the hydrophobicity of the compound, as well as the position of the hydroxyl group. 430 Compared to nerolidol solubilized in DMSO, HP- $\beta-C D / N e r$ inclusion complex exhibited 4 fold 431 higher $\mathrm{MIC}$ and $\mathrm{MBC}$ values and a more rapid bactericidal activity. Indeed, HP- $\beta$-CD/Ner 432 inclusion complex was proven effective against L. fermentum in culture medium. The high 433 demand for the replacement of synthetic food additives by natural molecules encourages the 434 application of nerolidol in food. Moreover, due to the physico-chemical limitations of the 435 application of natural bioactive components in food, the use of encapsulation systems has 436 recently became a widely investigated novel approach for the delivery of bioactive compounds in 437 food products. Therefore, further studies could be realized to investigate the antibacterial activity 438 of free and encapsulated nerolidol in different food products including fruit juices, alcoholic 439 beverages, and milk products. This evaluation would lead to a better understanding of the

440 antibacterial potency of natural molecules such as nerolidol, under their free and complexed 441 form, in various types of food matrices and under various conditions.

\section{Acknowledgments}

443 The authors thank the Research Funding Program at the Lebanese for supporting this project. 


\section{$444 \quad$ Conflict of Interest}

445 The authors declare no conflict of interest.

446

447

448

449

450

\section{References}

451 [1] C. Lacerda, L. Thorsen, R. Freitas, L. Jespersen, Strain-specific probiotics properties of 452 Lactobacillus fermentum, Lactobacillus plantarum and Lactobacillus brevis isolates from 453 Brazilian food products, Food Microbiol. 36 (2013) 22-29. doi:10.1016/j.fm.2013.03.010.

454 [2] L.H. Ledenbach, R. T. Marshall, Microbiological spoilage of dairy products, in: W.H. 455 456 457 Sperber, M.P. Doyle (Eds.), Compendium of the Microbiological Spoilage of Foods and Beverages, Springer, New York, USA, 2009, pp. 41-67. doi:10.1007/978-1-4419-08261_2.

[3] K.R. Nath, B.J. Kostak, Etiology of white spot defect in swiss cheese made from pasteurized milk, J. Food Prot. 49 (1986) 718-723.

[4] J.A. Kurmann, Studies of the defect excessive development of eyes in Gruyere cheese, Dtsch. Molkereiztg. 84 (1963) 1364-1366.

[5] B.J. Juven, Identification of chemical constituents of tomato juice which affect the heat resistance of Lactobacillus fermenturn, J. of Appl. Bacteriol. 54 (1983) 335-338. https://doi.org/10.1111/j.1365-2672.1983.tb02625.x 
465

466

467

468

469

470

471

472

473

474

475

476

477

478

479

480

481

482

483

484

485

[6] M. Parish, D. Higgins, lsolattion and identification of lactic acid bacteria from samples of citrus Molasses and unpasteurized orange juice, J. Food Sci. 53 (1988) 645-646. https://doi.org/10.1111/j.1365-2621.1988.tb07775.x

[7] A.E.H. Shearer, A.S. Mazzotta, R. Chuyate, D.E. Gombas, Heat resistance of juice spoilage microorganisms, J. Food Prot. 65 (2002) 1271-1275.

[8] B. Ray, Fundamental food microbiology, Third ed., CRC Press, Boca Raton, Florida, 2005.

[9] R. Robinson, C. Batt, Encyclopedia of Food Microbiology, second ed., Elsevier Science, 2014.

[10] A. Matthews, A. Grimaldi, M. Walker, E. Bartowsky, P. Grbin, V. Jiranek, Lactic acid bacteria as a potential source of enzymes for use in vinification, Appl. Environ. Microbiol. 70 (2004) 5715-5731. doi:10.1128/AEM.70.10.5715-5731.2004.

[11] C.G. Edwards, K.M. Haag, M.D. Collins, R.A. Hutson, Y.C. Huang, Lactobacillus kunkeei sp . nov. : a spoilage organism associated with grape juice fermentations, J. Appl. Microbiol. 84 (1998) 698-702.

[12] E.J. Bartowsky, Bacterial spoilage of wine and approaches to minimize it, Lett. Appl. Microbiol. 48 (2009) 149-156. doi:10.1111/j.1472-765X.2008.02505.x.

[13] O. Erkmen, T.F. Bozoglu, Food Microbiology: Principles Into Practice, 2 Volume Set, John Wiley \& Sons, 2016.

[14] N.A. Bokulich, C.W. Bamforth, N.A. Bokulich, W. Bamforth, The microbiology of malting and brewing, Microbio.l Mol. Biol. Rev. 77 (2013) 157-172. doi:10.1128/MMBR.0006012. 
[15] L. Dolezil, B.H. Kirsop, Variations amongst beers and lactic acid bacteria relating to beer spoilage, J. Inst. Brew. 86 (1980) 122-124. https://doi.org/10.1002/j.20500416.1980.tb03969.x

[16] K.R. Aneja, R. Dhiman, N.K. Aggarwal, A. Aneja, Emerging preservation techniques for controlling spoilage and pathogenic microorganisms in fruit juices, Int. J. Microbiol. (2014). doi:10.1155/2014/758942.

[17] A. Mayer, E. Harel, Phonoloxidase and their significance in fruit and vegetables, in: P.F. Fox (Ed.), Food Enzymology, Elsevier applied science, London, UK, 1991, pp. 373-398.

[18] W. Messens, J. Van Camp, A. Huyghebaert, The use of high pressure to modify the functionality of food proteins, Trends Food Sci. Technol. 8 (1997) 107-112. https://doi.org/10.1016/S0924-2244(97)01015-7

[19] A.I. V Ross, M.W. Griffiths, G.S. Mittal, H.C. Deeth, Combining nonthermal technologies to control foodborne microorganisms, Int. J. Food Microbiol. 89 (2003) 125-138. doi:10.1016/S0168-1605(03)00161-2.

[20] J. Raso, R. Paga, S. Condon, F.J. Sala, Influence of temperature andpressure on the lethality of ultrasound, Appl. Environ. Microbiol. 64 (1998) 465-471.

[21] S.P. Anand, N. Sati, Artificial preservatives and their harmful effects: looking toward nature for safer alternatives, Int. J. Pharm. Sci. Res. 4 (2013) 2496-2501. doi:10.13040/IJPSR.0975-8232.4(7).24960-01

[22] J. Gutierrez, G. Rodriguez, C. Barry-Ryan, P. Bourke, Efficacy of plant essential oils against foodborne pathogens and spoilage bacteria associated with ready-to-eat vegetables: antimicrobial and sensory screening, J. Food Prot. 71 (2008) 1846-1854. 
[23] M.M. Cowan, Plant products as antimicrobial agents, Clin. Microbiol. Rev. 12 (1999) 564582. doi:10.1016/j.tibtech.2009.09.002.

[24] M. Gutiérrez-larraínzar, J. Rúa, I. Caro, C. De Castro, D. De Arriaga, M.R. García-armesto, P. del Valle, Evaluation of antimicrobial and antioxidant activities of natural phenolic compounds against foodborne pathogens and spoilage bacteria, Food Control. 26 (2012) 555-563. doi:10.1016/j.foodcont.2012.02.025.

[25] S.J. Lee, J.I. Han, G.S. Lee, M.J. Park, I.G. Choi, K.J. Na, E.B. Jeung, Antifungal effect of eugenol and nerolidol against Microsporum gypseum in a guinea pig model, Biol. Pharm. Bull. 30 (2007) 184-188. https://doi.org/10.1248/bpb.30.184

[26] I. Kubo, H. Muroi, M. Himejima, Antimicrobial activity of green tea flavor components and their combination effects, J. Agric. Food Chem. 40 (1992) 245-248. doi:10.1021/jf00014a015.

[27] B.F. Brehm-Stecher, E.A. Johnson, Sensitization of Staphylococcus aureus and Escherichia coli to antibiotics by the sesquiterpenoids nerolidol, farnesol, bisabolol, and apritone, Antimicrob. Agents Chemother. 47 (2003) 3357-3360. doi:10.1128/AAC.47.10.33573360.2003

[28] M. Zhao, H. Wang, B. Yang, H. Tao, Identification of cyclodextrin inclusion complex of chlorogenic acid and its antimicrobial activity, Food Chem. 120 (2010) 1138-1142. doi:10.1016/j.foodchem.2009.11.044.

[29] A. Blanco-Padilla, K.M. Soto, M. Hernández Iturriaga, S. Mendoza, Food antimicrobials nanocarriers, Sci. World J. 2014 (2014) 1-11. doi:10.1155/2014/837215.

[30] J. Weiss, S. Gaysinsky, M. Davidson, J. McClements, Nanostructured Encapsulation Systems: Food Antimicrobials, in: E. by, G. Barbosa-Cánovas, A. Mortimer, D. Lineback, 
W. Spiess, K. Buckle, P. Colonna (Eds.), Global Issues in Food Science and Technology, Academic Press, San Diego, 2009, pp. 425-479. doi:10.1016/B978-0-12-374124-0.000247.

[31] G. Astray, C. Gonzalez-Barreiro, J.C. Mejuto, R. Rial-Otero, J. Simal-Gándara, A review on the use of cyclodextrins in foods, Food Hydrocoll. 23 (2009) 1631-1640. doi:10.1016/j.foodhyd.2009.01.001.

[32] E.M.M. Del Valle, Cyclodextrins and their uses: a review, Process Biochem. 39 (2004) 1033-1046. doi:10.1016/S0032-9592(03)00258-9.

[33] J. Azzi, L. Auezova, P.E. Danjou, S. Fourmentin, H. Greige-Gerges, First evaluation of drug-in-cyclodextrin-in-liposomes as an encapsulating system for nerolidol, Food Chem. 255 (2018) 399-404. doi:10.1016/j.foodchem.2018.02.055.

[34] E.R. Sanders, Aseptic Laboratory Techniques : Plating Methods 2. Streak Plate Procedure : Isolation of bacterial colonies using the quadrant method, J. Vis. Exp. 63 (2012) 1-18. doi:10.3791/3064.

[35] E.R.S. Nkanwen, D. Gatsing, D. Ngamga, S.P.C. Fodouop, P. Tane, Antibacterial agents from the leaves of Crinum purpurascens herb (Amaryllidaceae), Afr. Health Sci. 9 (2009) 264-269.

[36] K. Lewis, F.M. Ausubel, Prospects for plant-derived antibacterials, Nat Biotech. 24 (2006) 1504-1507. doi:10.1038/nbt1206-1504

[37] W.K. Chan, L.T.H. Tan, K.G. Chan, L.H. Lee, B.H. Goh, Nerolidol: A sesquiterpene alcohol with multi-faceted pharmacological and biological activities, Molecules. 21 (2016) 529. doi:10.3390/molecules21050529. 
[38] N. Togashi, H. Hamashima, A. Shiraishi, Y. Inoue, A. Takano, Antibacterial activities against Staphylococcus aureus of terpene alcohols with aliphatic carbon chains, J. Essent. Oil Res. 22 (2010) 263-269. doi:10.1080/10412905.2010.9700321.

[39] P.A. Cornwell, B.W. Barry, Sesquiterpene components of volatile oils as skin penetration enhancers for the hydrophilic permeant 5-fluorouracil, J. Pharm. Pharmacol. 46 (1994) 261-269.

[40] T. Hada, A. Shiraishi, S. Furuse, Y. Inoue, Y. Hamashima, H. Matsumoto, K. Masuda, K. Shiojima, J. Shimada, Inhibitory effects of terpenes on the growth of Staphylococcus aureus, Nat. Med. 57 (2003) 64-67.

[41] R. Tao, C.Z. Wang, Z.W. Kong, Antibacterial/antifungal activity and synergistic interactions between polyprenols and other lipids isolated from Ginkgo Biloba L. leaves, Molecules. 18 (2013) 2166-2182. doi:10.3390/molecules18022166.

[42] aM. Simoes, S. Rocha, M. Coimbra, M. Vieira, Enhancement of Escherichia coli and Staphylococcus aureus antibiotic susceptibility using sesquiterpenoids, Med. Chem. 4 (2008) 616-623. doi:10.2174/157340608786242016.

[43] O. Gonçalves, R. Pereira, F. Gonçalves, S. Mendo, M.A. Coimbra, S.M. Rocha, Evaluation of the mutagenicity of sesquiterpenic compounds and their influence on the susceptibility towards antibiotics of two clinically relevant bacterial strains, Mutat. Res. 723 (2011) 1825. doi:10.1016/j.mrgentox.2011.03.010.

[44] M. Egervärn, M. Danielsen, S. Roos, H. Lindmark, S. Lindgren, Antibiotic susceptibility profiles of Lactobacillus reuteri and Lactobacillus fermentum, J. Food Prot. 70 (2007) 412418. 
[45] I. Klare, C. Konstabel, G. Werner, G. Huys, V. Vankerckhoven, G. Kahlmeter, B. Hildebrandt, S. Müller-Bertling, W. Witte, H. Goossens, Antimicrobial susceptibilities of Lactobacillus, Pediococcus and Lactococcus human isolates and cultures intended for probiotic or nutritional use, J. Antimicrob. Chemother. 59 (2007) 900-912. doi:10.1093/jac/dkm035.

[46] K.Y. Gfeller, M. Roth, L. Meile, M. Teuber, Sequence and genetic organization of the 19.3$\mathrm{kb}$ erythromycin- and dalfopristin-resistance plasmid pLME300 from Lactobacillus fermentum ROT1, Plasmid. 50 (2003) 190-201. doi:10.1016/j.plasmid.2003.08.001.

[47] P. De Oliva-Neto, F. Yokoya, Susceptibility of Saccharomyces cerevisiae and lactic acid bacteria from the alcohol industry to several antimicrobial compounds, Braz. J. Microbiol. 32 (2001) 10-14. doi:10.1590/S1517-83822001000100003.

[48] A.B. Florez, M.S. Ammor, B. Mayo, A.H.A.M. van Hoek, H.J.M. Aarts, G. Huys, Antimicrobial susceptibility profiles of 32 type strains of Lactobacillus, Bifidobacterium, Lactococcus and Streptococcus spp., Int. J. Antimicrob. Agents. 31 (2008) 484-504. doi:10.1016/0002-9610(92)90118-B.

[49] O. Neto, P. De, F.A. de Lima, K.C. da Silva, D.F. da Silva, A.F.A. Carvalho, C. dos Santos, Chemical inhibition of the contaminant Lactobacillus fermentum from distilleries producing fuel bioethanol, Braz. Arch. Biol. Technol. 57 (2014) 441-447. doi:10.1590/S1516-8913201401214.

[50] J.F. Li, J.X. Zhang, Z.G. Wang, Y.J. Yao, X. Han, Y.L. Zhao, J.P. Liu, S.Q. Zhang, Identification of a cyclodextrin inclusion complex of antimicrobial peptide CM4 and its antimicrobial activity, Food Chem. $221 \quad$ (2017) 296-301. doi:10.1016/j.foodchem.2016.10.040. 
[51] C. Dima, M. Cotarlet, tiberius Balaes, G. Bahrim, P. Alexe, S. Dima, Encapsulation of Coriander essential oil in beta-cyclodextrin: Antioxidant and antimicrobial properties evaluation, Rom. Biotechnol. Lett. 19 (2014) 9128-9140.

[52] I.I. Salem, N. Düzgünes, Efficacies of cyclodextrin-complexed and liposome-encapsulated clarithromycin against Mycobacterium avium complex infection in human macrophages, Int. J. Pharm. 250 (2003) 403-414. https://doi.org/10.1016/S0378-5173(02)00552-5

[53] T.A. Andrade, T.S. Freitas, F.O. Araújo, P.P. Menezes, G.A.A. Dória, A.S. Rabelo, L.J. Quintans-Júnior, M.R.V. Santos, D.P. Bezerra, M.R. Serafini, I.R.A. Menezes, P.S. Nunes, A.A.S. Araújo, M.S. Costa, F.F. Campina, A.T.L. Santos, A.R.P. Silva, H.D.M. Coutinho, Physico-chemical characterization and antibacterial activity of inclusion complexes of Hyptis martiusii Benth essential oil in $\beta$-cyclodextrin, Biomed. Pharmacother. 89 (2017) 201-207. doi:10.1016/j.biopha.2017.01.158.

[54] E.H. Santos, J.A. Kamimura, L.E. Hill, C.L. Gomes, Characterization of carvacrol betacyclodextrin inclusion complexes as delivery systems for antibacterial and antioxidant applications, LWT - Food Sci. Technol. 60 (2015) 583-592. doi:10.1016/j.lwt.2014.08.046.

[55] J. Sikkema, J.A. de Bont, B. Poolman, Mechanisms of membrane toxicity of hydrocarbons, Microbiol. Rev. 59 (1995) 201-222. doi:0146-0749/95/\$04.00+0.

[56] M.C. Selestino Neta, C. Vittorazzi, A.C. Guimarães, J.D.L. Martins, M. Fronza, D.C. Endringer, R. Scherer, Effects of $\beta$-caryophyllene and Murraya paniculata essential oil in the murine hepatoma cells and in the bacteria and fungi 24-h time-kill curve studies, Pharmaceut. Biol. 55 (2017) 190-197. doi:10.1080/13880209.2016.1254251. 
620 [57] K. Knobloch, A. Pauli, B. Iberl, H. Weigand, N. Weis, Antibacterial and antifungal 621 properties of essential oil components, J. Essent. Oil Res. 1 (1989) 119-128.

622 doi:10.1080/10412905.1989.9697767.

623 [58] H. Dorman, S. Deans, Antimicrobial agents from plants: antibacterial activity of plant 624 volatile oils, J. Appl. Microbiol. 88 (2000) 308-316.

625 [59] R. Kotan, S. Kordali, A. Cakir, Screening of Antibacterial activities of twenty-one 626 oxygenated monoterpenes, Z. Naturforsch. C. 62 (2007) 507-513.

627 [60] D. Kalemba, A. Kunicka, Antibacterial and antifungal properties of essential oils, Curr. 628 Med. Chem. 10 (2003) 813-829.

629

[61] I. Kubo, H. Muroi, M. Himejima, A. Kubo, Antibacterial activity of long-chain alcohols: 630 The role of hydrophobic alkyl groups, Bioorg. Med.Chem. Lett. 3 (1993) 1305-1308. https://doi.org/10.1016/S0960-894X(00)80336-4

[62] Y. Inoue, A. Shiraishi, T. Hada, K. Hirose, H. Hamashima, J. Shimada, The antibacterial effects of terpene alcohols on Staphylococcus aureus and their mode of action, FEMS Microbiol. Lett. 237 (2004) 325-331. doi:10.1016/j.femsle.2004.06.049.

[63] R. Gharib, A. Najjar, L. Auezova, C. Charcosset, Interaction of selected phenylpropenes with dipalmitoylphosphatidylcholine membrane and their relevance to antibacterial activity, J. Membr. Biol. 250 (2017) 259-271. doi:10.1007/s00232-017-9957-y.

[64] S. Shrivastava, T. Bera, A. Roy, G. Singh, P. Ramachandrarao, D. Dash, Characterization of enhanced antibacterial effects of novel silver nanoparticles, Nanotechnol. 18 (2007) 225103. doi:10.1088/0957-4484/18/22/225103. 
641 [65] D.P. Tamboli, D.S. Lee, Mechanistic antimicrobial approach of extracellularly synthesized

642

643

644

645

646

647

648

649

650

651

652

653

654

655

656

657

658

659

660

661

662

663

silver nanoparticles against gram positive and gram negative bacteria, J. Hazard. Mater. 260 (2013) 878-884. doi:10.1016/j.jhazmat.2013.06.003.

[66] F. Nazzaro, F. Fratianni, L. De Martino, R. Coppola, V. De Feo, Effect of essential oils on pathogenic bacteria, Pharmaceut. 6 (2013) 1451-1474. doi:10.3390/ph6121451.

[67] H. Liang, Q. Yuan, F. Vriesekoop, F. Lv, Effects of cyclodextrins on the antimicrobial activity of plant-derived essential oil compounds, Food Chem. 135 (2012) 1020-1027. doi:10.1016/j.foodchem.2012.05.054.

[68] J.B. Russell, Another explanation for the toxicity of fermentation acids at low $\mathrm{pH}$ : anion accumulation versus uncoupling, J. Appl. Bacteriol. 73 (1992) 363-370. doi:10.1111/j.1365-2672.1992.tb04990.x.

[69] A.F. Sánchez-Maldonado, A. Schieber, M.G. Gänzle, Structure-function relationships of the antibacterial activity of phenolic acids and their metabolism by lactic acid bacteria, J. Appl. Microbiol. 111 (2011) 1176-1184. doi:10.1111/j.1365-2672.2011.05141.x.

[70] S. Griffin, S.G. Wyllie, J. Markham, Determination of octanol-water partition coefficient for terpenoids using reversed-phase high-performance liquid chromatography, J. Chromatogr. A. 864 (1999) 221-228. doi:10.1016/S0021-9673(99)01009-2.

[71] S. Ohtsubo, T. Fujita, A. Matsushita, E. Kumamoto, Inhibition of the compound action potentials of frog sciatic nerves by aroma oil compounds having various chemical structures, Pharmacol. Res. Perspect. 3 (2015) e00127. doi:10.1002/prp2.127.

[72] O. Sensch, W. Vierling, W. Brandt, M. Reiter, Effects of inhibition of calcium and potassium currents in guinea-pig cardiac contraction: comparison of $\beta$-caryophyllene oxide, 
eugenol, and nifedipine, Brit. J. Pharmacol. 131 (2000) 1089-1096. doi:10.1038/sj.bjp.0703673.

[73] C. Hansch, A. Leo, D. Hoekman, Exploring QSAR: Hydrophobic, electronic, and steric constants, American Chemical Society, Washington DC, 1995.

[74] A.F. El-Kattan, C.S. Asbill, N. Kim, B.B. Michniak, The effects of terpene enhancers on the percutaneous permeation of drugs with different lipophilicities, Int. J. Pharms. 215 (2001) 229-240. doi:10.1016/S0378-5173(00)00699-2.

[75] J. Li, E.M. Perdue, S.G. Pavlostathis, R. Araujo, Physicochemical properties of selected monoterpenes, Environ. Int. 24 (1998) 353-358. doi:10.1016/S0160-4120(98)00013-0.

[76] C. Schmid, R. Steinbrecher, H. Ziegler, Partition coefficients of plant cuticles for monoterpenes, Trees. 6 (1992) 32-36. doi:10.1007/BF00224496.

[77] H.S. Camargos, R.A. Moreira, S.A. Mendanha, K.S. Fernandes, M.L. Dorta, A. Alonso, Terpenes increase the lipid dynamics in the Leishmania plasma membrane at concentrations similar to their IC50 values, PLOS ONE. 9 (2014) e104429. doi:10.1371/journal.pone.0104429.

[78] A. Ben Arfa, S. Combes, L. Preziosi-Belloy, N. Gontard, P. Chalier, Antimicrobial activity of carvacrol related to its chemical structure, Lett. Appl. Microbiol. 43 (2006) 149-154. doi:10.1111/j.1472-765X.2006.01938.x.

[79] A.A. Taherpour, H. Maroofi, O. Bajelani, K. Larijani, Chemical composition of the essential oil of Valeriana alliariifolia Adams of Iran, Nat. Prod. Res. 24 (2010) 973-978. doi:10.1080/14786410902900010.

[80] J.R. Clare, Automatic dishwashing compositions comprising diacyl peroxide bleach and blooming perfume, EP1360269B1, 2005. 
[81] R. Lun, D. Varhanickova, W.-Y. Shiu, D. Mackay, Aqueous solubilities and octanol-water partition coefficients of cymenes and chlorocymenes, J. Chem. Eng. Data. 42 (1997) 951953. doi:10.1021/je970069v.

[82] M. Kfoury, D. Landy, L. Auezova, H. Greige-Gerges, S. Fourmentin, Effect of cyclodextrin complexation on phenylpropanoids' solubility and antioxidant activity, Beilstein J. Org. Chem. 10 (2014) 2322-2331. doi:10.3762/bjoc.10.241.

[83] N.C. Dias, M.I. Nawas, C.F. Poole, Evaluation of a reversed-phase column (Supelcosil LCABZ) under isocratic and gradient elution conditions for estimating octanol-water partition coefficients, Analyst. 128 (2003) 427-433. doi:10.1039/B300574G.

[84] J.A. Rothwell, A.J. Day, M.R.A. Morgan, Experimental determination of octanol-water partition coefficients of quercetin and related flavonoids, J. Agric. Food Chem. 53 (2005) 4355-4360. doi:10.1021/jf0483669.

[85] M.E. Herbig, D.H. Evers, Correlation of hydrotropic solubilization by urea with $\log D$ of drug molecules and utilization of this effect for topical formulations, Eur. J. Pharm. Biopharm. 85 (2013) 158-160. doi:10.1016/j.ejpb.2013.06.022.

[86] S. Ritter, W.H. Hauthal, G. Maurer, Partition coefficients of some environmentally important organic compounds between 1-octanol and water from reversed-phase highperformance liquid chromatography, J. Chem. Eng. Data. 39 (1994) 414-417. doi:10.1021/je00015a003.

[87] G.N. Reiner, D.O. Labuckas, D.A. García, Lipophilicity of some GABAergic phenols and related compounds determined by HPLC and partition coefficients in different systems, J. Pharm. Biomed. Anal. 49 (2009) 686-691. doi:10.1016/j.jpba.2008.12.040. 
709 [88] O. Wesołowska, M. Kuzdzał, J. Strancar, K. Michalak, Interaction of the chemopreventive

710

711

712

713

714

715

716

717

718

719

720

721

722

723

724

725

726

727

728

3

4

15

16

24
agent resveratrol and its metabolite, piceatannol, with model membranes, Biochim. Biophys. Acta. 1788 (2009) 1851-1860. doi:10.1016/j.bbamem.2009.06.005.

7

8

\section{$9 \quad$ Figure legends}

Fig.1. Chemical structure of terpenic compounds.

1 Fig. 2. Chemical structure of phenolic compounds.

2 Fig. 3. Nerolidol $(50 \mu \mathrm{M})$ and HP- $\beta$-CD/Ner complex $(200 \mu \mathrm{M}$ Ner $)$ time-kill analysis against $L$. fermentum at $37^{\circ} \mathrm{C}$ under anaerobic conditions. 


\begin{tabular}{|c|c|c|c|c|c|c|c|c|c|c|c|c|c|c|c|c|c|}
\hline $\begin{array}{l}\text { Inhibition } \\
(\%)\end{array}$ & $\begin{array}{l}28.5 \\
\pm \\
1.8\end{array}$ & 100 & 100 & 0 & $\begin{array}{l}89 \\
\pm \\
2.4\end{array}$ & 100 & $\begin{array}{l}80.9 \\
\pm \\
1.4\end{array}$ & 100 & 0 & 100 & $\begin{array}{l}75.7 \\
\pm \\
4.4\end{array}$ & 100 & 100 & 100 & 100 & ND & 100 \\
\hline \multicolumn{18}{|l|}{$250 \mu \mathrm{M}$} \\
\hline $\begin{array}{l}\text { Bacterial } \\
\text { kill }(\%)\end{array}$ & ND & 0 & ND & ND & ND & ND & ND & ND & ND & 0 & ND & 100 & ND & ND & 0 & ND & ND \\
\hline $\begin{array}{l}\text { Inhibition } \\
(\%)\end{array}$ & ND & 100 & ND & ND & ND & ND & ND & ND & ND & 100 & ND & 100 & ND & ND & 100 & ND & ND \\
\hline \multicolumn{18}{|l|}{$100 \mu \mathrm{M}$} \\
\hline $\begin{array}{l}\text { Bacterial } \\
\text { kill }(\%)\end{array}$ & ND & 0 & ND & ND & ND & ND & ND & ND & ND & 0 & ND & 100 & ND & ND & 0 & ND & ND \\
\hline $\begin{array}{l}\text { Inhibition } \\
(\%)\end{array}$ & ND & 0 & ND & ND & ND & ND & ND & ND & ND & 0 & ND & 100 & ND & ND & $\begin{array}{l}91.4 \\
\pm \\
0.8\end{array}$ & ND & ND \\
\hline
\end{tabular}

739 ND: Not determined

740

741

742

743 
744 Table 2: Bactericidal and anti-proliferative activity of phenolic compounds against $\boldsymbol{L}$. 745 fermentum.

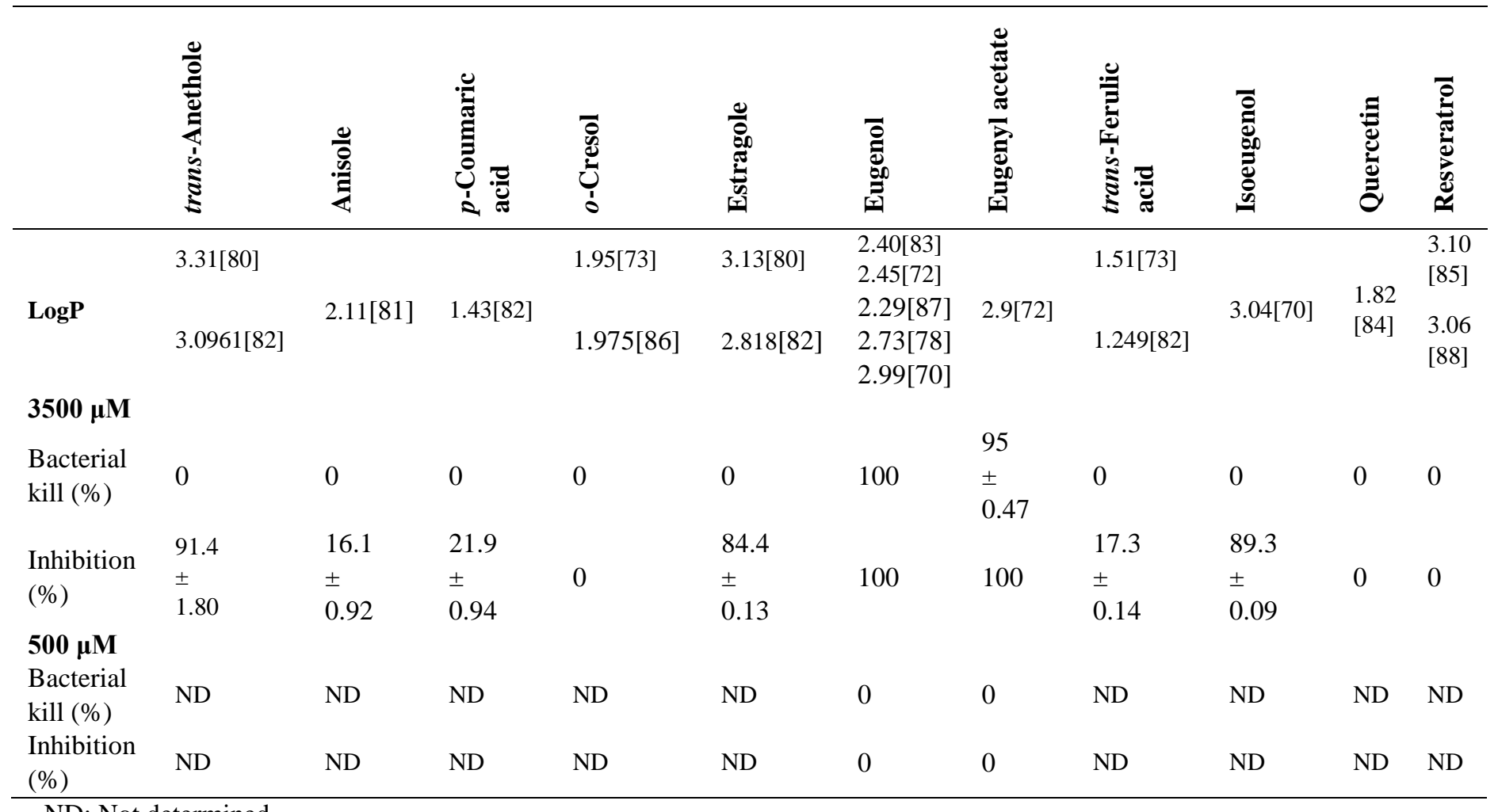


756 Table 3: MIC values of common antibiotics against $L$. fermentum.

\begin{tabular}{llll}
\hline Antibiotic & MIC $(\mathbf{m g} / \mathbf{l})$ & MIC $(\boldsymbol{\mu M})$ & Reference \\
\hline Clindamycin & $>64$ & $>150.60$ & {$[46]$} \\
Chloramphenicol & $4^{\mathrm{a}}$ & 12.38 & {$[45]$} \\
Erythromycin & $>128-256$ & $>174.40-348.81$ & {$[46]$} \\
Gentamicin & $4-8$ & $8.38-16.75$ & {$[44]$} \\
Kanamycin & 64 & 132.10 & {$[48]$} \\
Metronidazole & $>40$ & $>233.7$ & {$[49]$} \\
N-alkyl & & & \\
dimethylbenzyl & 8 & 25.11 & {$[47]$} \\
ammonium chloride & & & \\
Nitrofurantoin & 15 & 62.98 & {$[49]$} \\
Novobiocin & $>16$ & $>26.12$ & {$[46]$} \\
Polymixin B & 64 & 49.17 & {$[48]$} \\
& $16^{\mathrm{a}}$ & 27.51 & {$[45]$} \\
Streptomycin & 16 & 27.51 & {$[48]$} \\
& $8-128$ & $13.76-220.09$ & {$[44]$} \\
Teicoplanin & $>128$ & $>220.09$ & {$[46]$} \\
Tobramycin & $>256^{\mathrm{a}}$ & $>134.19-163.65$ & {$[45]$} \\
Vancomycin & 9128 & $>273.79$ & {$[46]$} \\
& $>256^{\mathrm{a}}$ & 66.24 & {$[48]$} \\
\hline Valyes of & $>176.64$ & {$[45]$}
\end{tabular}

$757{ }^{\mathrm{a}}$ Values of $\mathrm{MIC}_{90}$ 


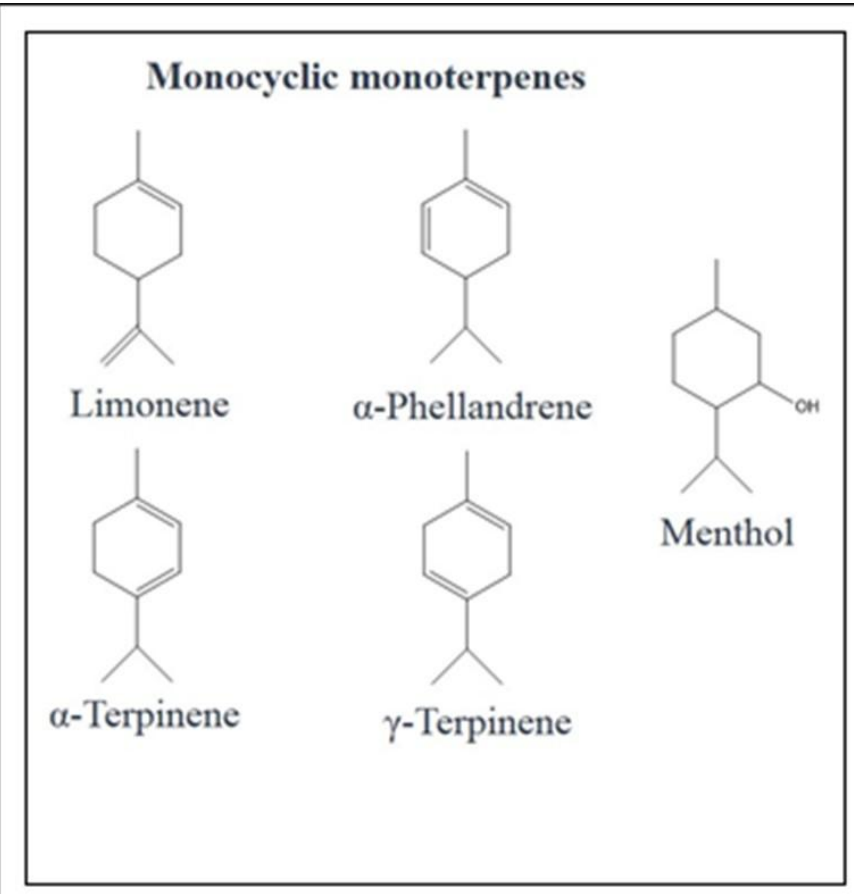

Bicyclic monoterpenes and derivatives

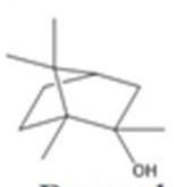

Borneol

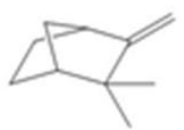

Camphene

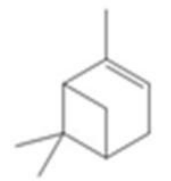

$\alpha$-Pinene

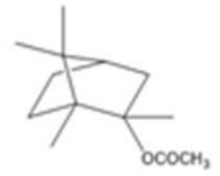

Bornyl acetate

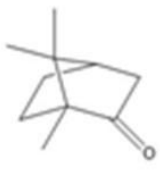

Camphor

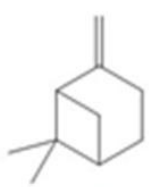

$\beta$-Pinene
Acyclic terpene alcohols and derivatives<smiles>CCC=C(C)CCC=C(C)C</smiles>

Geraniol

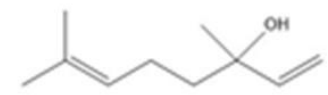

Linalool

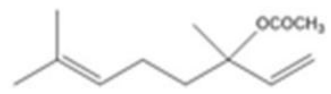

Linalyl acetate

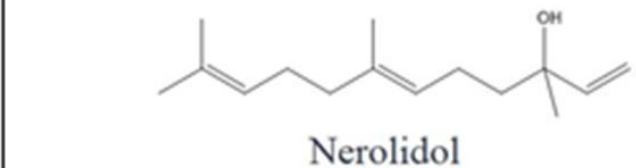

Nerolidol

Fig. 1 


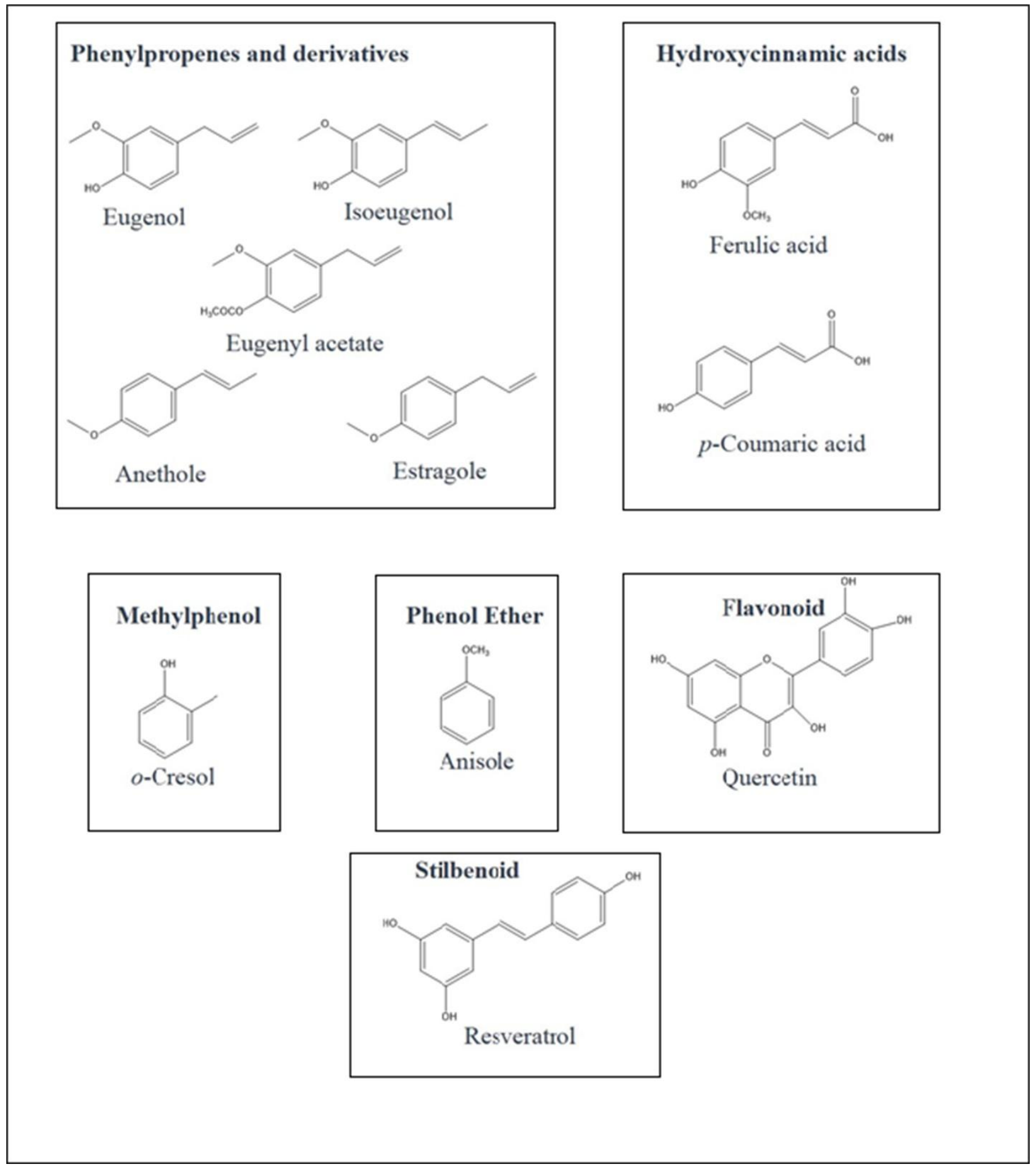

Fig. 2 


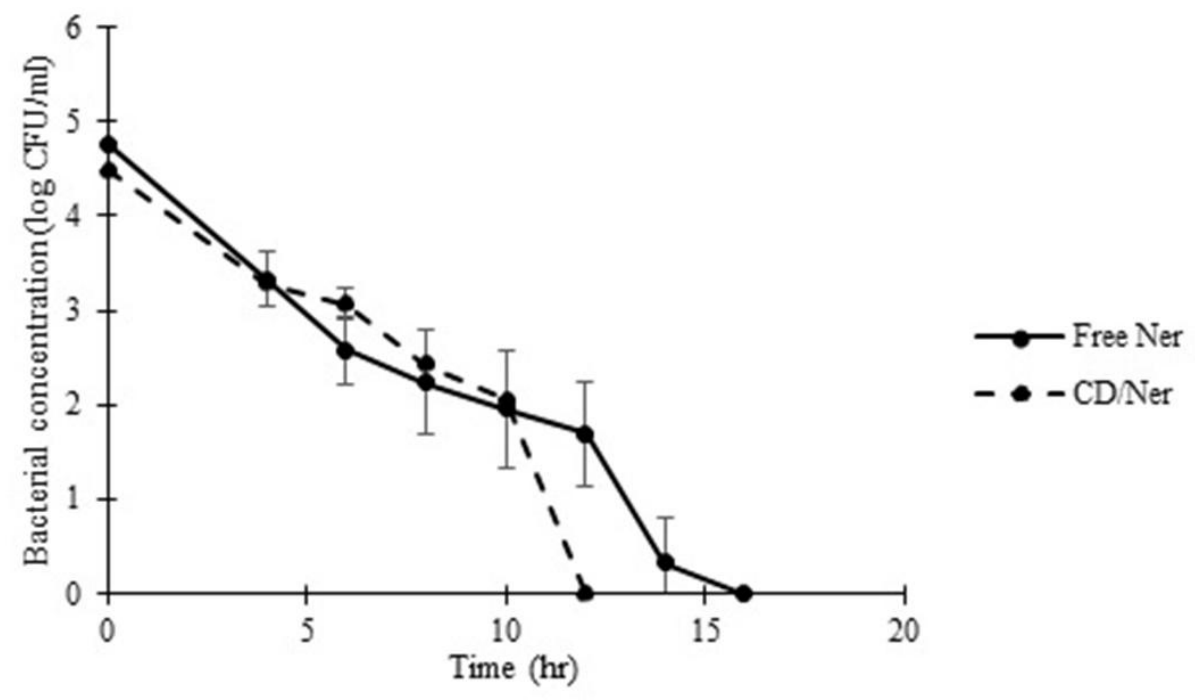

767

$768 \quad$ Fig. 3

769

770

771

772

773

774

775

776

777

778

779 